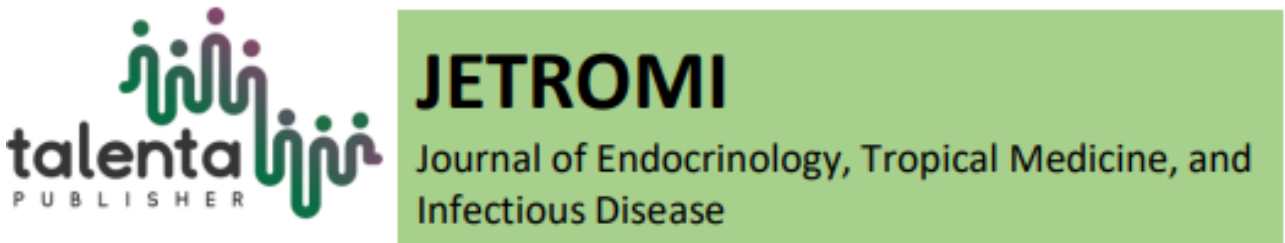

\title{
The Correlation between Personal Hygiene and Intestinal Parasitic Infection in Students of SDN 060889, SDN 060894, and SDN 060831 Medan
}

\author{
Yolanda Rebecca Tambunan*1, Yoan Carolina Panggabean ${ }^{2}$ \\ ${ }^{1}$ Faculty of Medicine, Universitas Sumatera Utara \\ ${ }^{2}$ Department of Parasitology, Faculty of Medicine, Universitas Sumatera Utara
}

\begin{abstract}
:
Background. Intestinal parasitic infections are globally endemic diseases. The presence of parasites in the intestine will lead to growth disturbance. Knowledge of personal hygiene is necessary for responding to an illness or other health problems. This study was conducted to determine the correlation between personal hygiene and intestinal parasitic infections in students.
\end{abstract}

Method. This study is an observational analytic study with a cross-sectional design. Samples of this study were taken from students in grades IV, V, VI of SDN 060889, SDN 060894, and SDN 060831 Medan who met the inclusion and exclusion criteria, as many as 62 people. The research data are primarily collected in the form of questionnaires, and fecal specimens examined microscopically using the Kato-Katz and Ether Formol Concentration method. The data that has been collected will be analyzed using bivariate analysis with the chi-square test.

Results. From 62 respondents, it was found that 26 (41.93\%) respondents suffer from intestinal parasitic infections. There were $16(25.80 \%)$ respondents who had poor personal hygiene, while $46(74.19 \%)$ others had good personal hygiene. A significant correlation was found between personal hygiene and intestinal parasitic infections in study respondents $(p=0.001)$.

Conclusions. There is a significant correlation between personal hygiene and intestinal parasitic infections in this study

Keyword: Intestinal Parasites, Personal Hygiene, Primary School

\begin{abstract}
ABSTRAK:
Latar belakang. Infeksi parasit usus adalah penyakit endemik yang global. Keberadaan parasit di usus akan menyebabkan gangguan pertumbuhan. Pengetahuan tentang kebersihan pribadi diperlukan untuk menanggapi penyakit atau masalah kesehatan lainnya. Penelitian ini dilakukan
\end{abstract}

${ }^{*}$ Corresponding author at: Faculty of Medicine, Universitas Sumatera Utara, Medan, Indonesia

E-mail address: yolandarebecca20@gmail.com 
untuk mengetahui korelasi antara kebersihan pribadi dengan infeksi parasit usus pada siswa sekolah dasar.

Metode. Studi ini adalah bersifat analitik observasional dengan desain potong lintang $c$. Sampel penelitian ini diambil sebanyak 62 orang dari siswa kelas IV, V, VI SDN 060889, SDN 060894, dan SDN 060831 Medan yang memenuhi kriteria inklusi dan eksklusi,. Data penelitian dikumpulkan dalam bentuk kuesioner, dan spesimen tinja diperiksa secara mikroskopis dengan menggunakan metode Konsentrasi Kato-Katz dan Ether Formol. Data yang telah dikumpulkan akan dianalisis menggunakan analisis bivariat dengan tes chi-square.

Hasil. Dari 62 responden, ditemukan bahwa 26 (41,93\%) responden menderita infeksi parasit usus. Ada $16(25,80 \%)$ responden yang memiliki kebersihan pribadi yang buruk, sementara 46 (74,19\%) lainnya memiliki kebersihan pribadi yang baik. Terdapat korelasi yang signifikan antara kebersihan pribadi dengan infeksi parasit usus pada responden $(p=0,001)$.

Kesimpulan. Terdapat korelasi signifikan antara kebersihan pribadi dan infeksi parasit usus.

Kata kunci: Parasit Usus, Kebersihan Pribadi, Sekolah Dasar

Received 20 January 2020 | Revised 18 June 2021 | Accepted 30 August 2021

\section{Introduction}

Intestinal parasitic infections (soil-transmitted helminths and protozoa) are globally endemic diseases and causing the largest morbidity worldwide. Intestinal parasitic infections have become a serious health problem in developing countries, especially in children.[1] The presence of parasites in the intestine will lead to nutrient loss, causing growth disturbance of both body and brain cells, so that someone will experience growth disruption, decreased immunity, and also decreased concentration of learning.[2]

There are various types of intestinal parasites, both commensal and pathogenic types. Intestinal protozoa species that are pathogenic to humans include Entamoeba histolytica, Blastocystis hominis, and Giardia lamblia. Types of intestinal worms are generally classified in STH (soiltransmitted helminths), worms whose transmission is through the soil, such as Ascaris lumbricoides, Trichuris trichiura, and Hookworms.[3]

Indonesia is a developing country with tropical climate conditions, high humidity, and low sanitation and hygiene conditions, making this country a suitable place for the distribution of various intestinal parasites.[4] The prevalence of intestinal parasitic infections in Indonesia is relatively high, especially in poor populations and living in dense environments with poor sanitation, lack of latrines, and inadequate clean water facilities.[5]

Children are at risk of getting soil-transmitted helminths (STH) infection because children's activities often come into contact with the soil where the worms grow and develop.[6] In 
Indonesia, until 2013, a survey of helminthiasis infections in primary school children showed figures ranging from $0 \%$ to $85.9 \%$ (survey in 175 districts/cities) with an average prevalence of 28.12\%.[7] The largest age group that is infected is at the age of 6-12 years or the primary school level.[6] Parasitic infections in primary school students can occur in several ways, through contaminated food or drink, or being ingested through the hands after handling soil containing the infective egg, or in other ways, infective larvae in the soil penetrate through intact foot's skin.[8]

Clean and healthy living behaviors are factors that affect individual health. This behavior involves knowledge of the importance of personal hygiene and attitude in responding to an illness or other health problems.[9]

The study aims to research the correlation between personal hygiene and intestinal parasitic infection.

\section{Method}

This study is an observational analytic study with a cross-sectional design. The samples were chosen by the total sampling method. The study subjects who met the inclusion criteria were taken from students in grades IV, V, and VI of SDN 060889, SDN 060894, and SDN 060831 as many as 62 people. The inclusion criteria included students who are willing to become study respondents and get parental approval, students who bring their stool, and students who filled out the questionnaire. A validated questionnaire is used to assess personal hygiene. Stool specimens are examined microscopically using the Kato-Katz and Formol-Ether Concentration technique in the Parasitology Laboratory, Faculty of Medicine, Universitas Sumatera Utara. Exclusion criteria included students who were not present on the day when the stool pots were distributed, and students who have been taking anti-parasite drugs for the past six months. If there are either helminth eggs, helminth larvae, protozoan cysts, or protozoan trophozoites found in the examination of the stool sample, then the sample is said to be infected with intestinal parasites. The questions in the questionnaire cover the following categories: handwashing habits, location of defecation, cleanliness of drinking water, the habit of cutting nails, the habit of nail-biting, the habit of using footwear, bathing habits, and cleanliness of fruits eaten.

The questionnaire contains ten questions and is measured by score. Personal hygiene of respondents is categorized as good if the score is $76-100 \%$ and classified as bad if the score $<76 \%$. This study was carried out after ethical approval was obtained from the Health Research Ethics Committee of the faculty of medicine of Universitas Sumatera Utara (No. 163/TGL/KEPK FK USU-RSUP HAM/2019), and all participants gave their fully informed consent before participated in the study 
Statistically analytic

The data were analyzed using SPSS software and presented in tabular form. The analysis used was bivariate analysis with the chi-square test to evaluate the correlation between variables. Pvalue $<0,05$ was accepted as an indication of statistical significance.

\section{Results}

In table 1, from 62 respondents, there were 16 respondents from SDN 060889 (25.8\%) and each 23 respondents from SDN 060894 (37.1\%) and SDN 060831 (37.1\%). There were 27 males (43.5\%) and 35 females (56.5\%). Respondents data based on grade level were divided into 26 respondents in grade IV (41.9\%), 22 in grade V (35.5\%), and 14 respondents in grade VI $(22.6 \%)$.

Table 1 Characteristics of Respondents

\begin{tabular}{|c|c|c|}
\hline Characteristics & Frequency (n) & Percentage (\%) \\
\hline \multicolumn{3}{|l|}{ Primary School: } \\
\hline - $\quad$ SDN 060889 & 16 & $25.8 \%$ \\
\hline - $\quad$ SDN 060894 & 23 & $37.1 \%$ \\
\hline - $\quad$ SDN 060831 & 23 & $37.1 \%$ \\
\hline \multicolumn{3}{|l|}{ Gender: } \\
\hline - Male & 27 & $43.5 \%$ \\
\hline - Female & 35 & $56.5 \%$ \\
\hline \multicolumn{3}{|l|}{ Grade level: } \\
\hline - IV & 26 & $41.9 \%$ \\
\hline V & 22 & $35.5 \%$ \\
\hline$-\quad V I$ & 14 & $22.6 \%$ \\
\hline Total & 62 & \\
\hline
\end{tabular}

Based on table 2, it is shown that from 46 respondents who had good personal hygiene, there were 12 respondents (19.4\%) positive for intestinal parasitic infections and 34 respondents (54.8\%) negative for intestinal parasitic infections. While from 16 respondents who had poor personal hygiene, there were 14 respondents $(22.6 \%)$ positive for intestinal parasitic infections, and 2 respondents $(3.2 \%)$ were negative for intestinal parasitic infections. From the chi-square test result $(\mathrm{p}=0.001)$, means that there were significant correlations between personal hygiene and intestinal parasitic infections in this study. 
Table 2 Relationship between Personal Hygiene and Intestinal Parasitic Infections in Respondents

\begin{tabular}{|c|c|c|c|c|c|c|c|}
\hline \multirow{3}{*}{$\begin{array}{l}\text { Personal } \\
\text { Hygiene }\end{array}$} & \multicolumn{4}{|c|}{ Intestinal Parasitic Infections } & \multirow{2}{*}{\multicolumn{2}{|c|}{ Total }} & \multirow{3}{*}{$\mathrm{P}$-value } \\
\hline & \multicolumn{2}{|c|}{ Positive } & \multicolumn{2}{|c|}{ Negative } & & & \\
\hline & $\mathrm{N}$ & $\%$ & $\mathrm{~N}$ & $\%$ & $\mathrm{~N}$ & $\%$ & \\
\hline Good & 12 & 19.4 & 34 & 54.8 & 46 & 74.2 & 0.001 \\
\hline $\mathrm{Bad}$ & 14 & 22.6 & 2 & 3.2 & 16 & 25.8 & \\
\hline Total & 26 & 41.9 & 36 & 58.1 & 62 & 100 & \\
\hline
\end{tabular}

\section{Discussion}

Parasites are defined as organisms that obtain food and shelter from the host. For a parasitic to be outlined as intestinal, it must have an intestinal life cycle stage. Additionally, it may have a life cycle stage in the heart, circulation, lung, tissue, and other animals on the surrounding.[11] Although all ages can be infected with intestinal parasites, the highest prevalence can be found in children.[12]

Personal hygiene is believed to be a factor that affects the risk of intestinal parasitic infections, shown by several clinical studies. The components of cleanliness behavior in primary school children that cause intestinal parasitic infections in this study were the habit of washing hands, the location of defecation, drinking water, cutting nails, nail-biting, use of footwear, bathing,

The overall infection prevalence rate was 41.9\%, with a higher prevalence in SDN 060831 (21\%), followed by SDN 060894 (14.5\%) and SDN 060889 (6.5\%). This prevalence rate was higher than the rate reported from a primary school in Harjosari I Village, Medan Amplas District, Medan City,[13] where the prevalence rate was $40 \%$. Similar lower results were also obtained from other studies such as in primary school in Batanghari riverside, Jambi City,[5] a primary school in Subdistrict Tembalang, Semarang City,[14] and primary school in Ranomeeto District, Konawe Selatan District,[15] with prevalence rates 12\%, 20\%, 3.3\%, respectively. On the other hand, the higher prevalence was also observed from a primary school in Bantargebang, Bekasi City,[16] and in the village of Bagan Kuala, Serdang Bedagai Regency,[17] the prevalence were $62 \%$ and $75 \%$ respectively. These variations in prevalence might be due to differences in climatic conditions, environmental sanitation, economic and educational status of parents and study subjects, and previous control efforts.[18]

The parasites found in this study were dominated by Ascaris lumbricoides (38.5\%), Trichuris trichiura (11.5\%), hookworm (11.5\%), and Blastocystis hominis (11.5\%). However, different results from the widest parasites found in the study, reported by Tangel et al,[19] at the coastal area in Wori district, North Minahasa regency, and Simatupang et al,[4] study on preschool children in Kedung Cowek Sub-District, Bulak District, Surabaya City. The difference of findings in each study is determined by many factors; some of the probabilities are geographical 
factors and weather/climate factors that are suitable for the development of intestinal parasites (STH).

In this study, personal hygiene was significantly associated with intestinal parasitic infection $(\mathrm{p}<0.05)$. A similar result was also reported from Taabo, Côte d'Ivoire, South Africa, where it found that inadequate sanitation and hygiene behavior are associated with soil-transmitted helminths and intestinal protozoa infections with the prevalences for hookworm, S. haematobium, T. trichiura, S. mansoni, and A. lumbricoides of 33.5\%, 7.0\%, 1.6\%, 1.3\%, and $0.8 \%$, respectively. Only very few individuals were identified with moderate or heavy helminth infection intensities, except S. haematobium (25.9\% of the infections were classified as heavy, i.e., $\geq 50 \mathrm{eggs} / 10 \mathrm{ml}$ of urine). The prevalences of the pathogenic intestinal protozoa G. intestinalis and E. histolytica/E. dispar were $15.0 \%$ and $14.4 \%$, respectively. The most common intestinal protozoa were E. coli and B. hominis with respective prevalences of $45.0 \%$ and $35.4 \% .[20]$.

\section{Conclusion}

There was a significant correlation between personal hygiene and intestinal parasitic infections in students of SDN 060889, SDN 060894, and SDN 060831 Medan. With the result of this study, it is expected that parents can play a role in teaching personal hygiene to their children, and maintaining the cleanliness of the home environment. Likewise for the schools, to be able to conduct a training program on clean and healthy life behavior to the students to avoid intestinal parasitic infections, in addition, sanitation of the school environment and school facilities such as toilets need to be improved

\section{REFERENCES}

[1] Novianty, S. Pasaribu H., S. \& Pasaribu A. P. 'Faktor Resiko Kejadian Kecacingan pada Anak Usia Pra Sekolah', J Indon Med Assoc, 2018,vol. 68, no. 2, p:87.

[2] Wulandari, A. Saleh, I. \& Silviana. 'Factors Related to Worm Infection (Soil-Transmitted Helminth) and Learning Achievement Among Elementary Students at Work Area of Puskesmas Panggur,' Jurnal Mahasiswa dan Peneliti Kesehatan - JuMantik, 2015,p: 29.

[3] Kesetyaningsih, T. W. Riswari, R. A. \& Pitaka, R. T. 'Distribusi Prevalensi Infestasi Parasit Usus Pada Balita Penderita Gizi Buruk di Kasihan, Bantul, Yogyakarta Berdasarkan Faktor Resiko', Mutiara Medika, 2010,vol.10, no.2, p:135-41.

[4] Simatupang, R. Utami, P. D. \& Setianingsih H. 'Interaksi Antara Perilaku, Status Gizi, Sosio Ekonomi dan Infeksi Parasit Usus pada Anak Usia Prasekolah di Kelurahan Kedung Cowek, Kecamatan Bulak, Surabaya' in Kumpulan Abstrak PIN-PAAI : Pendalaman Anatomi Sistem Muskuloskeletal dan Neuroanatomi dalam Upaya Meningkatkan Kualitas Pencegahan, Diagnosis, dan Penatalaksanaan, Mukhlis M. F., A., Departemen Anatomi Fakultas Kedokteran Universitas Padjajaran, Bandung. 2013 
[5] Hardiyanti, L. T. \& Umniyati, S. R. 'Higiene Buruk dan Infeksi Parasit Usus pada Anak Sekolah Dasar di Tepi Sungai Batanghari', Berita Kedokteran Masyarakat, 2017,vol. 33, no. 11, p:521-8.

[6] Sofia, R. Perbandingan Akurasi Pemeriksaan Metode Direct Slide dengan Metode KatoKatz pada Infeksi Kecacingan, Bagian Parasitologi Fakultas Kedokteran Universitas Malikussaleh, Aceh. 2017

[7] Kementerian Kesehatan Republik Indonesia. 'Kondisi Pencapaian Program Kesehatan Anak Indonesia' [Internet], accessed 19 Mei 2019, Available at: http://www.depkes.go.id/article/view/15021800001/kondisi-pencapaian-programkesehatan-anak-indonesia.html

[8] Lestari, D. 'Hubungan Higienitas Personal Siswa dengan Kejadian Kecacingan Nematode Usus', Jurnal Ilmu dan Teknologi Kesehatan, 2016,vol. 4, no. 1.

[9] Notoatmodjo, S. Promosi Kesehatan Teori dan Aplikasi, Rineka Cipta, Jakarta. 2010

[10] Fransisca, R. O., Iriani A. D., Mutiksa F. A., Izati, S. \& Utami, R. K., 'Hubungan Infeksi Parasit Usus dengan Pengetahuan Perilaku Hidup Bersih Sehat pada Anak SD Bekasi, 2012', eJKI, vol. 3, no. 1, pp. 19.2012

[11] Ali, Y. Intestinal parasitic Infections among School-age Children In Mekaneselam Health Center, Borena, Northeast Ethiopia, Addis Ababa University, Ethiopia.2016

[12] Sofia, L. Sumarni, S. \& Ipa, M. 'Fingernail biting was increase the risk of soil-transmitted helminth (STH) infection in elementary school children,' Health Science Journal of Indonesia, vol. 2, no. 2, pp. 84. 2011

[13] Simorangkir, H. A. H., Hubungan Perilaku, Higienitas Personal dan Sanitasi Lingkungan Rumah dengan Kejadian Infeksi Soil Transmitted Helminths (STH) pada Siswa-Siswi SD Negeri 060925 Kelurahan Harjosari 1 Kecamatan Medan Amplas Tahun 2015, Universitas Sumatera Utara, Medan.2015

[14] Yulianto, E. Hubungan Higiene Sanitasi dengan Kejadian Penyakit Cacingan pada Siswa Sekolah Dasar Negeri Rowosari 01 Kecamatan Tembalang Kota Semarang Tahun Ajaran 2006/2007, Universitas Negeri Semarang, Semarang. 2007

[15] Putri, P. A. Hubungan Higiene Perorangan dengan Infeksi Ascaris lumbricoides pada Siswa SDN 05 Ranomeeto Kecamatan Ranomeeto Kabupaten Konawe Selatan, Politeknik Kesehatan Kendari, Kendari.2017

[16] Firdaus, M. Y. \& Sungkar, S. Prevalensi Infeksi Parasit Usus pada Murid SD X, Bantargebang, 2012.

[17] Surbakti, R. A. Hubungan Higiene Perorangan Anak Sekolah dengan Infeksi Cacing STH pada Lingkungan yang Tercemar Telur/Larva Cacing STH pada Lingkungan yang Tercemar Telur/Larva Cacing STH di Desa Bagan Kuala Pemkab. Serdang Bedagai, Universitas Sumatera Utara, Medan. 2015

[18] Suliman, M. A., Magboul, A. M., Mohammed, H. Y., Tamomh, A. G., Bakhit, H. A., Altoum, S. A., \& Ahmed, S. M. 'Prevalence of Intestinal Parasitic Infections and Associated Risk Factors among School Children in White Nile State, Sudan,' Journal of Infectious Diseases and Diagnosis, vol. 4, no. 1.2019

[19] Tangel, F. Tuda, J. S., B., \& Pijoh, V. D. 'Infeksi Parasit Usus pada Anak Sekolah Dasar di Pesisir Pantai Kecamatan Wori Kabupaten Minahasa Utara', Jurnal e-Biomedik (eBm), vol. 4, no. 1, pp. 71.2016

[20] Schmidlin, T. Hurlimann, E. Silue, K. D., Yapi, R. B., Houngbedji C. Kouadio, B. A., et al. 'Effects of Hygiene and Defecation Behavior on Helminths and Intestinal Protozoa Infections in Taabo, Cote d'Ivoire,' PLUS One Journal, vol. 8.2013 